\title{
ANALISIS SISTEM DU PONT SEBAGAI SALAH SATU ALAT UNTUK MENILAI KINERJA KEUANGAN PERUSAHAAN \\ (STUDI PADA PERUSAHAAN PROPERTY REAL ESTATE YANG TERDAFTAR DI BEI TAHUN 2010 - 2014)
}

\author{
Liliek Nur Sulistiyo \\ Diah Ayu Retno Asih \\ Universitas PGRI Madiun \\ dretnoasih@yahoo.com
}

\begin{abstract}
This study aims to determine how the Du Pont analysis system can be used as a tool to assess the financial performance of Property and Real Estate listed on the Stock Exchange 2010-2014. Du Pont Analysis System is Return On Ivestment (ROI) generated through the multiplication of the advantages of component component sales as well as the efficient use of total assets in generating profits. The data used in this study was obtained from Companies Condensed Financial Statements Property and Real Estate in 2010 to 2014 issued by each of the companies concerned. The company's sample using purposive sampling, sample worth using as many as five companies. The analysis technique used to assess the financial performance of Property and Real Estate is a method of Du Pont System consists of three steps: (1) Determining the Total Asset Turnover (2) Net Profit Margin (3) Return On Investment (ROI). Based on the analysis using the Du Pont System for Property and Real Estate companies, 5 companies 4 companies which have a value below the average ROI. Analysis showed that the company PT.Ciputra Development Tbk were able to prove the performance of the company to generate profits, the better because it has above-average ROI of the company, ie $5.73 \%$.
\end{abstract}

Keywords : Total Asset Turnover, Net Profit Margin, Return Of Investment

\section{PENDAHULUAN}

Indonesia merupakan salah satu negara dengan jumlah penduduk terbesar di dunia. Sejalannya trend global, Indonesia telah mengalami proses urbanisasi. Bisnis properti di tanah air pun menjadi booming karena ada banyak rumah, apartemen dan kondominium yang akan dibangun di wilayah perkotaan Indonesia untuk memenuhi permintaan di masa mendatang, dengan perkembangan perekonomian Indonesia membuat para pelaku bisnis mengoptimalkan kreativitas dan inovasinya di bidang properti tersebut.

Pihak manajemen dituntut untuk siap menghadapi masalah seperti perdagangan bebas yang sudah di depan pintu dengan selalu mengintrospeksi kondisi perusahaan terutama dari segi financialnya. Fenomena tersebut menjelaskan bahwa perusahaan sebagai organisasi profit oriented untuk selalu meningkatkan kuantitas serta kualitas 
usahanya sehingga keuntungan yang diharapkan akan tercapai.

Kondisi perusahaan dapat di analisa dengan laporan keuangan yang pada umumnya terdiri dari laporan laba/rugi, laporan perubahan modal, neraca dan laporan arus kas. Pihak-pihak yang berkepentingan terhadap informasi keuangan tersebut harus melakukan analisa terlebih dahulu agar laporan keuangan lebih informatif dan bermanfaat.

Alat ukur yang digunakan untuk menganalisa laporan keuangan diantaranya adalah Analisis Rasio, Analisis Nilai Tambah Pasar (Market Value Added/MVA), Analisis Nilai Tambah Ekonomis (Economic Value Added/ EVA) dan Balance Score Card/BSC, Analisis Capital Asset, Management, Equity, and Liquidity (CAMEL)dan Du Pont System (Warsono, 2003:24)

Peneliti menggunakan $D u$ Pont System untuk menganalisa laporan keuangan tersebut. Analisis Du Pont System ini bersifat menyeluruh karena mencakup tingkat efisiensi perusahaan dalam penggunaan aktivanya dan dapat mengukur tingkat keuntungan atas penjualan produk yang dihasilkan oleh perusahaan tersebut.Tujuan analisis ini digunakan untuk mengetahui sejauh mana efektvitas perusahaan dalam memutar modalnya,sehingga analisis ini mencakup berbagai rasio.

System Du Pont merupakan penggabungan rasio aktivitas / perputaran aktiva dengan rasio laba/profit margin atas penjualan dan menunjukkan bagaimana keduanya berinteraksi dalam menentukan Return On Invesment (ROI), yaitu profitabilitas atas aktivas yang dimiliki perusahaan. Rasio laba atas penjualan (profit margin) dipengaruhi oleh tingkat penjualan dan laba bersih yang dihasilkan. Berarti profit margin ini mencakup pula seluruh biaya yang digunakan dalamo perasional perusahaan. Rasio aktivitas sendiri dipengaruhi oleh penjualan dan total aktiva. Dapat dikatakan bahwa analisis ini tidak hanya menfokuskan pada laba yang dicapai, tetapi juga pada investasi yang digunakan untuk menghasilkan laba tersebut. (Daulat Freddy dalam Hildawati:2014)

Du Pont System ini lebih tepat jika diterapkan pada perusahaan cabang/divisi/departemen/pusat investasi. Melalui analisis ini perusahaan dapat menilai kinerja keuangan divisi/departemen/pusat investasinya dengan melihat efektivitas penggunaan aktiva dalam memperoleh laba bersih, sehingga pada akhirnya perusahaan pusat dapat mengambil kebijaksanaan yang tepat atas divisi/ pusat investasinya.

Penelitian terdahulu menggunakan Du Pont System dan Fuzzy Logic untuk mengambil keputusan investasi saham, adapun perusahaan yang diteliti peneliti terdahulu adalah Pertambangan, Perkebunan, Otomotif, Perbankan, Industri makanan dan minuman, Property, Energi dan Mineral, Telekomunikasi, Manufacture, Industri Dasar dan Kimia, sedangkan Perusahaan Properti dan Real Estate di Galeri Investasi Bursa Efek Inonesia (BEI) cukup menarik untuk dijadikan objek penelitian karena untuk saat ini bisnis tersebut sangat dibutuhkan oleh konsumen yang membutuhkan hunian. Guna melihat dan menilai tingkat efektivitas operasional suatu 


$\begin{array}{lrr}\text { perusahaan, } & \text { tidak } & \text { hanya } \\ \text { menggunakan } & \text { kepekaan } & \text { dan } \\ \text { ketajaman para } & \text { manajer } & \text { secara } \\ \text { kualitatif saja, tetapi } & \text { harus } \\ \text { menggunakan } & \text { metode } & \text { secara } \\ \text { kuantitatif. } & & \\ \end{array}$

\section{TEORI PENUNJANG}

Laporan keuangan

Laporan keuangan merupakan salah satu informasi keuangan yang bersumber dari intern perusahaan yang bersangkutan (Munawir, 2003:5). Menurut (Irham Fahmi,2013:2), laporan keuangan merupakan suatu informasi yang menggambarkan kondisi keuangan suatu perusahaan, dan lebih jauh informasi tersebut dapat dijadikan sebagai gambaran kinerja keuangan perusahaan tersebut

Ikatan Akuntansi Indonesia No.1 (2004:2) dinyatakan bahwa laporan keuangan merupakan bagian dari proses pelaporan keuangan. Laporan keuangan lengkap terdiri dari neraca, laporan laba rugi, laporan perubahan posisi keuangan (yang dapat disajikan dalam berbagai cara, misalnya laporan ekuitas atau laporan arus dana). Tujuan pelaporan keuangan untuk membantu investor, kreditur, dan pihak-pihak lain menaksir besarnya, waktu ( timing), serta tingkat ketidakpastian aliran kas suatu perusahaan. (Mamduh, 2009:61).

Menurut Irham Fahmi (2013:29) komponen keuangan terdiri dari: (1) Neraca Merupakan informasi yang menggambar tentang kondisi dan situasi current asset, non current asset, liabilitaes, dan shareholders equity serta berbagai item lainnya yang termasuk disana, untuk selanjutnya informasi tersebut dijadikan sebagai alat dalam mendukung proses pengambilan keputusan (decision making); (2) laporan laba rugi merupakan salah satu dari banyak bagian suatu paket laporan keuangan dan seperti bagian lainnya, laporan laba rugi merupakan bagian dari produk berbagai pilihan, dilaporkan, seperti halnya kebijakan bisnis, kondisi ekonomi, dan banyak variabel yang mempengaruhi hasil hasil yang dilaporkan; (3) laporan aliran kas dimaksudkan untuk mengisi gap informasi seperti laporan neraca dan laba rugi, bagaimana aliran kas masuk dan keluar perusahaan, untuk membiayai ekspansinya. Tujuan pokok aliran kas adalah untuk memberikan informasi mengenai penerimaan dan pembayaran kas perusahaan selama periode tertentu. Tujuan kedua laporan aliran kas adalah untuk memberikan informasi mengenai efek kas dari kegiatan invesatsi, pendanaan, dan operasi perusahaan selama periode tertentu.

\section{Analisis laporan keuangan}

Analisa laporan keuangan merupakan suatu informasi yang ditujukan untuk masyarakat, pemerintah, pemasok, dan kreditur, pemilik perusahaan atau pemegang saham, manajemen perusahaan, investor, pelanggan dan karyawan yang diperlukan secara tetap untuk mengukur kondisi dan efisiensi operasi perusahaan. Analisa dari laporan keuangan ini bersifat relatif karena didasarkan pada pengetahuan dan menggunakan rasio atau nilai relatif (Ridwan dan Inge, 2003:123) dalam Evida Anugrahani (2007).

Menurut Mamduh dan Abdul (2009:111) pada dasarnya ada 
dua cara yang dapat dilakukan dalam perbandingan rasio financial perusahaan. Kedua cara yaitu, pertama Cross-Sectional yaitu Perbandingan rasio-rasio suatu perusahaan dengan perusahaan lain yang sejenis dan sebanding dengan rata-rata rasio industri. Kedua adalah Time Series Analysis Perbandingan rasio saat ini dengan rasio masa lalu dan di masa yang akan datang untuk perusahaan yang sama.

Macam-macam rasio menurut Mamduh dan Abdul (2009:74) ada lima macam. (1) Rasio Likuiditas, Rasio likuiditas mengukur kemampuan likuiditas jangka pendek perusahaan dengan melihat aktiva lancar perusahaan relatif terhadap utang lancarnya, (2) Rasio Aktivitas, rasio ini melihat pada beberapa aset kemudian menentukan beberapa tingkat aktivitas-aktivitas tersebut pada tingkat kegiatan tertentu, (3) Rasio Solvabilitas, rasio ini mengukur kemampuan perusahaan memenuhi kewajiban-kewajiban jangka panjangnya, (4) Rasio Profitabilitas, rasio ini mengukur kemampuan perusahaan menghasilkan keuntungan (profitabilitas) tingkat penjualan, aset dan modal saham yang tertentu. (5) Rasio Pasar, adalah rasio pasar yang mengukur harga pasar relatif terhadap nilai buku.

\section{Pengertian Analisis Du Pont System}

Analisis Du Pont System adalah Return On Ivestment ( ROI ) yang dihasilkan melalui perkalian antara keuntungan dari komponenkomponen sales serta efisiensi penggunaan total assets di dalam menghasilkan keuntungan tersebut
(Syamsudin, 2001:640) dalam Evida Anugrahani (2007).

Menurut Syafarudin (1993: 128) dalam Evida Anugrahani (2007) analisis Du Pont System penting bagi manajer untuk mengetahui faktor mana yang paling kuat pengaruhnya antara profit margin dan total asset turnover terhadap Return On Ivestment (ROI). Di samping itu dengan menggunakan analisis ini, pengendalian biaya dapat diukur dan efisiensi perputaran aktiva sebagai akibat turun naiknya penjualan tersebut.

\section{Keunggulan dan Kelemahan Analisis Du Pont System}

Adapun keunggulan analisis $\mathrm{Du}$ Pont System antara lain (Harahap, 1998:333):

a) Caranya sebenarnya hampir sama dengan analisis laporan keuangan biasa, namun pendekatannya lebih integrative dan menggunakan komposisi laporan keuangan sebagai elemen analisisnya.

b) Penguraian komponen laporan keuangan menjadi komponen kecil sampai pada pos-pos individual akan membantu memberikan gambaran lebih lengkap bagi analisis.

Sedangkan kelemahan dari analisis Du Pont System adalah (Harahap:1998:341):

a) Model ini sangat simpel sehingga tidak banyak memberikan informasi yang lebih rinci dan kritis karena sangat terbatas pada rentabilitas, dan likuiditas.

b) Kalau kita ingin informasi lain seperti leverage, prestasi divisi, solvabilitas, produktivitas, ke- 
adaan pembiayaan perusahaan tentu bukan dari model $d u$ pont ini.

\section{Pengertian Return On Investment (ROI)}

Return On Investment (ROI)

metode Du Pont adalah satu bentuk dari rasio profibilitas yang dimaksudkan untuk dapat mengukur kemampuan perusahaan dengan keseluruhan dana yang ditanamkan dalam aktiva yang digunakan untuk operasinya perusahaan untuk menghasilkan keuntungan ( Munawir, 2004:89). Besarnya Return On Ivestment (ROI) dipengaruhi oleh dua faktor :

1. Tingkat perputaran aktiva yang digunakan untuk operasi.

2. Profit Margin, yaitu besarnya keuntungan operasi yang dinyatakan dalam prosentase dan jumlah penjualan bersih. Dengan rumus sebagai berikut :

ROI = Net Profit Margin $x$ Total Asset Turnover

Sedangkan Return On

Invesment (ROI) merupakan analisis rasio keuangan yang menunjukan hasil (Return) atas jumlah aktiva yang digunakan dalam perusahaan atau suatu ukuran tentang efesiensi manajemen. Rasio ini menunjukan hasil dari seluruh aktiva yang dikendalikannya dengan mengabaikan sumber pendanaan dan biasanya rasio ini diukur dengan persentase. (Kasmir, 2010: 139).

$$
\text { Rumus yang }
$$

digunakan untuk mencari ROI menurut kasmir (2010: 139) adalah sebagai berikut :
$\mathrm{ROI}=\underline{\text { Laba setelah pajak }} \times 100 \%$ Total Asset

Menurut Munawir (2004:

91), kegunaan dari analisa Return On Investment (ROI) yaitu : (1) Sebagai salah satu kegunaannya yang prinsipil ialah sifatnya yang menyeluruh, (2) Apabila perusahaan dapat mempunyai data industri sehingga dapat diperoleh ratio industri, maka dengan analisa Return On Ivestment (ROI) ini dapat dibandingkan efisiensi penggunaan modal pada perusahaannya dengan perusahaan lain yang sejenis, sehingga dapat diketahui apakah perusahaaannya berada dibawah, sama, atau di atas rata-ratanya, (3) Analisa Return On Ivestment (ROI) pun dapat digunakan untuk mengukur efisiensi tindakantindakan yang dilakukan oleh devisi atau bagian, yaitu dengan mengalokasikan semua biaya dan modal ke dalam bagian yang bersangkutan, (4) Analisa Return On Ivestment (ROI) juga dapat digunakan untuk mengukur profitabilitas dari masing-masing produk yang dihasilkan oleh konsumen, (5) Return On Ivestment (ROI) selain berguna untuk keperluan kontrol, juga berguna untuk keperluan perencanaan. Sedangkan kelemahan dari ROI adalah (1) Kesukarannya dalam membandingkan rate of raturn suatu perusahaan dengan perusahaan lain yang sejenis, (2) Kelemahan lain dari teknik analisa ini adalah terletak pada adanya fluktuasi nilai dari uang (daya belinya), (3) Dengan menggunakan analisa rate of return atau Return On Ivestment (ROI) saja 
tidak akan dapat digunakan untuk mengadakan perbandingan antara dua perusahaan atau lebih dengan mendapatkan kesimpulan yang memuaskan.

\section{Price Earning Ratio (PER )}

Price Earning Ratio (PER) rasio harga / laba merupakan suatu rasio yang lazim di pakai untuk mengukur harga pasar (market price) setiap lembar saham biasa dengan laba per lembar saham. Rasio harga / laba ini mencerminkan penilaian pemodal terhadap pendapatan perusahaan dimasa mendatang. Rasio ini dihitung dengan membagi harga pasar per lembar saham dengan laba per lembar saham ( Henry Simamora, 2000:53).

Rasio harga/laba $=$
$\frac{\text { harga pasar sekarang per lembar saham }}{\text { Laba per lembar saham }}$

\section{Populasi dan Sampel}

Dalam penelitian ini populasinya adalah perusahaanperusahaan property dan real estate yang tercatat di Bursa Efek Indonesia yaitu sebanyak 46 perusahaan. Sampel dalam penelitian ini adalah (1) Perusahaan PT. Intiland Development Tbk., (2) Perusahaan PT. Kawasan Industri Jababeka Tbk.,
(3) Perusahaan
PT. Ciputra

Development Tbk., (4) Perusahaan PT. Sentul City Tbk., (5) Perusahaan PT. Bumi Citra Permai Tbk. tahun 2010 sampai dengan tahun 2014 yang sesuai kriteria.

\section{Jenis dan Sumber Data}

Sumber data yang digunakan penulis adalah data sekunder, yaitu laporan keuangan Tahun 2010-2014 lima perusahaan property real and estate, serta data lain yang mendukung laporan tersebut.

\section{Defini Operasional Variabel}

1. Perputaran Total Aktiva (Total Asset Turnover) adalah perbandingan antara jumlah penjualan perusahaan dengan seluruh harta/ aktiva perusahaan.

2. Rasio Laba Bersih (Net Profit Margin) adalah perbandingan antara laba bersih (laba sesudah biaya dan pajak) dengan penjualan bersih perusahaan.

3. Laba Operasi Bersih (Return On Investment) adalah satu bentuk dari rasio profitabilitas yang dimaksudkan untuk dapat mengukur kemampuan perusahaan dengan keseluruhan dana yang ditanamkan dalam aktiva yang digunakan untuk operasinya perusahaan untuk menghasilkan keuntungan. 


\section{Analisa dan Pembahasan}

Tabel 1

Hasil Analisa

\begin{tabular}{|c|c|c|c|c|c|}
\hline No & $\begin{array}{c}\text { Nama } \\
\text { Perusahaan }\end{array}$ & $\begin{array}{c}\text { Total Asset } \\
\text { Turnover }\end{array}$ & $\begin{array}{c}\text { Net Profit } \\
\text { Margin }\end{array}$ & $\begin{array}{l}\text { Return Of } \\
\text { Investasi }\end{array}$ & Kesimpulan \\
\hline 1. & $\begin{array}{l}\text { Intiland } \\
\text { Development } \\
\text { Tbk.(DILD) }\end{array}$ & 0,19 Kali & $24,30 \%$ & $4,59 \%$ & $\begin{array}{l}\text { Di bawah } \\
\text { rata-rata } \\
\text { kurang baik }\end{array}$ \\
\hline 2. & $\begin{array}{l}\text { Intiland } \\
\text { Development } \\
\text { Tbk.(DILD) }\end{array}$ & 0,25 Kali & $16,76 \%$ & $3,83 \%$ & $\begin{array}{l}\text { Di bawah } \\
\text { rata-rata } \\
\text { kurang baik }\end{array}$ \\
\hline 3. & $\begin{array}{l}\text { Ciputra } \\
\text { Development } \\
\text { Tbk.(CTRA) }\end{array}$ & 0,22 Kali & $25,47 \%$ & $5,73 \%$ & $\begin{array}{l}\text { Di atas rata- } \\
\text { rata } / \text { sangat } \\
\text { baik }\end{array}$ \\
\hline 4. & $\begin{array}{l}\text { Sentul City } \\
\text { Tbk-(BKSL) }\end{array}$ & 0,09 Kali & $30,53 \%$ & $2,80 \%$ & $\begin{array}{l}\text { Di bawah } \\
\text { rata-rata } \\
\text { kurang baik }\end{array}$ \\
\hline 5. & $\begin{array}{l}\text { Bumi Citra } \\
\text { Permai } \\
\text { Tbk.(BCIP) }\end{array}$ & 0,35 Kali & $12,71 \%$ & $4,92 \%$ & $\begin{array}{l}\text { Di bawah } \\
\text { rata-rata } \\
\text { kurang baik }\end{array}$ \\
\hline
\end{tabular}




\section{Pembahasan}

Penulis menggunakan metode $D u$ Pont System karena Menurut Syafarudin (1993:128) dalam Evida Anugrahani (2007) analisis Du Pont System penting bagi manajer untuk mengetahui faktor mana yang paling kuat pengaruhnya antara Profit Margin dan Total Asset Turnover terhadap Return On Ivestment (ROI). Di samping itu dengan menggunakan analisis ini, pengendalian biaya dapat diukur dan efisiensi perputaran aktiva sebagai akibat turun naiknya penjualan tersebut. Menurut (Harahap, 1998:333), Dengan penerapan System Du Pont perusahaan dapat menganalisis laporan keuangan karena sifat pendekatannya lebih integrative dan menggunakan komposisi laporan keuangan sebagai elemen analisisnya, karena Analisis laporan keuangan dapat digunakan untuk memprediksi masa depan, sedangkan dari sudut manajemen, analisis laporan keuangan digunakan untuk membantu mengantisipasi kondisi di masa depan dan yang lebih penting sebagai titik awal untuk perencanaan tindakan yang akan mempengaruhi peristiwa di masa depan (Brigham dan Houston, 2006). Analisis laporan keuangan merupakan alat penting untuk memperoleh informasi yang berkaitan dengan posisi keuangan perusahaan serta hasil-hasil yang telah dicapai sehubungan dengan pemilihan strategi perusahaan yang akan diterapkan. Dengan melakukan analisis laporan keuangan perusahaan, maka pimpinan perusahaan dapat mengetahui keadaan serta perkembangan finansial perusahaan serta hasil-hasil yang telah dicapai diwaktu lampau dan diwaktu yang sedang berjalan. Selain itu dengan menganalisis keuangan diwaktu lampau maka dapat diketahui kelemahan-kelemahan perusahaan serta hasil-hasilnya yang dianggap telah cukup baik dan mengetahui potensi kebangkrutan persahaan tersebut. Analisis metode Du Pont juga menguraikan komponen laporan keuangan menjadi komponen kecil sampai pada pos-pos individual sehingga dapat membantu para manajer dalam pengambilan keputusan karena akan membantu memberikan gambaran yang lebih lengkap, di bandingkan dengan metode lain, seperti Fuzzy Logic, yang pertama jika menggunakan Fuzzy Logic model Mamdani atau Sugeno atau model lain, penentuan model inference harus tepat, Mamdani biasanya cocok untuk masalah intuitive sedangkan Sugeno untuk permasalahan yang menangani control.Yang kedua jumlah Nilai Linguistik untuk setiap variabel, kita harus merubah nilai crisp menjadi nilai linguisik. Jumlah dari nilai linguistik yang digunakan harus sesuai dengan permasalahan yang akan kita selesaikan. Perusahaan menggunakan perusahaan property real and estate karena banyak masyarakat menginvestasikan modalnya di industri properti karena harga tanah yang cenderung naik tiap tahunnya. Penyebabnya adalah supply tanah bersifat tetap sedangkan demand akan selalu lebih besar seiring dengan pertambahan jumlah penduduk. Investasi pada industri properti pada umumnya bersifat jangka panjang dan akan tumbuh sejalan dengan pertumbuhan ekonomi (Indriyati, 2010).

Temuan yang terjadi di lima perusahaan diantaranya yaitu :

Pertama, perusahaan PT. Intiland Development Tbk. Pada tahun 2011 perusahaan mengalami penurunan pada Rasio Laba Bersih / Net Profit Margin.

Kedua, perusahaan PT. Kawasan Industri Jababeka Tbk. Hasil perhitungan rata - rata Return On Invesment ( ROI ) dari tahun 2010 sampai 2014 perusahaan PT. Kawasan Industri Jababeka Tbk. kurang baik dan berada jauh dari rata - rata industri.

Ketiga, perusahaan PT.Ciputra Development Tbk. Perusahaan PT.Ciputra Development Tbk. pada tahun 2011 Rasio Laba Bersih / Net Profit Margin sempat 
mengalami penurunan yaitu dari $23,00 \%$ pada tahun 2010 menjadi 22,68\% pada tahun 2011, akan tetapi setelah itu Rasio Laba Bersih / Net Profit Margin di tahun selanjutnya mengalami kenaikkan sehingga menghasilkan Return On Invesment (ROI) yang diatas rata - rata dan menunjukkan bahwa kinerja perusahaan dalam menghasilkan laba sangat baik.

Keempat, yaitu perusahaan PT.Sentul City Tbk. Pada perhitungan Rasio Laba Bersih / Net Profit Margin di tahun 2014 mengalami penurunan yang drastis yaitu sebesar $5,72 \%$ yang pada tahun sebelumnya sebesar $62,90 \%$ pada tahun 2013.

Kelima yaitu perusahaan PT. Bumi Citra Permai Tbk. Perusahaan PT. Bumi Citra Permai Tbk. dalam menghasilkan laba kurang baik.

\section{Kesimpulan dan Saran Kesimpulan}

Berdasarkan hasil penilaian kinerja keuangan pada Perusahaan Property and Real Estate yang terdapat Di BEI Tahun 2010-2014 dapat disimpulkan bahwa :

System Du Pont dapat digunakan untuk mengetahui perusahaan mana yang lebih banyak menghasilkan laba. Dari 5 perusahaan yang telah dilakukan peneliti, perusahaan PT. Ciputra Development Tbk dalam mengha-silkan laba yang sangat baik, hal ini dikarenakan setiap tahunnya mengalami peningkatan dari tahun 2010 sampai 2014.

Perusahaan dapat menerap-kan System Du Pont untuk menganalisis laporan keuangan karena sifat pendekatannya lebih integrative dan menggunakan komposisi laporan keuangan sebagai elemen analisisnya. Analisis metode $D u$ Pont juga menguraikan komponen laporan keuangan menjadi komponen kecil sampai pada pospos individual sehingga dapat membantu para manajer dalam pengambilan keputusan karena akan membantu memberikan gambaran yang lebih lengkap. System $D u$ Pont merupakan penggabungan rasio aktivitas/perputaran aktiva dengan rasio laba / Profit Margin atas penjualan dan menunjukkan bagaimana keduanya berinteraksi dalam menentukan Return On Invesment (ROI), yaitu profitabilitas atas aktiva yang dimiliki perusahaan.

\section{Saran}

Berdasarkan kesimpulan di atas, penulis memberikan saran-saran sebagai berikut :

Sebaiknya di setiap perusahaan menggunakan analisis Du Pont System, hal ini dikarenakan sistem ini dapat mengukur tingkat keuntungan atas penjualan produk yang dihasilkan oleh perusahaan. Dari analisis tersebut dapat diketahui sejauh mana efektvitas perusahaan dalam memutar modalnya,sehingga analisis ini mencakup berbagai rasio.

Selain itu, analisisis dengan menggunakan Du Pont System penting bagi manajer untuk mengetahui faktor mana yang paling kuat pengaruhnya antara Net Profit Margin dan Total Asset Turnover terhadap Return On Ivestment (ROI). Di samping itu dengan menggunakan analisis ini, pengendalian biaya dapat diukur dan efisiensi perputaran aktiva sebagai akibat turun naiknya penjualan tersebut, di bandingkan dengan metode lain, seperti Fuzzy Logic.

Daftar Pustaka

Abdul,Mamduh.2009. Analisis Laporan Keuangan. Yogyakarta: UPP STIM YKPN

Anugrahani, Evida. 2007. Analisis DU Pont Sistem Dalam Mengukur Kinerja Keuangan Perusahaan. Universitas Muhammadiyah Malang. Malang 
Arikunto, Suharsimi. 1989. Prosedur Penelitian suatu pendekatan Praktik. Jakarta: PT. Bina Aksara

Dziqron, Wuryaningsih. 2014. Penerapan Du Pont System Untuk Mengukur Kinerja Keuangan Perusahaan. Universitas Muhammadiyah Jakarta. Jakarta

Fahmi, Irham. 2013. Analisis Laporan Keuangan. Bandung: Alfabeta

Fitriana, Nur. 2014. Analisis Sistem Du Pont Sebagai Alat Untuk Menilai Pertumbuhan Laba Perusahaan Tekstil. STIESIA Surabaya. Surabaya

Freddy, Daulat, Hildawati. 2014. Analisis Kinerja Keuangan Perusahaan dengan Meng-gunakan Metode Du Pont System. Universitas Esa Unggul. Jakarta

J.Lies, Thomas. 2008. Ratio Analysis Featuring The Du Pont Method: An Overlooked Topic In The Finance Module of Small Business Management And Entrepreneurship Courses. University of Houston. Downtown

Meivilana, Winda. 2014. Analisis Kinerja Keuangan Perusa-haan Dengan Sistem Du Pont. Universitas Negeri Surabaya. Surabaya

Munawir. 2004. Analisa Laporan Keuangan. Yogyakarta: Liberty

Munawir. 2003. Auditing Modern. Yogyakarta :BPFE

Prina A, Ryandra. Mangesti, Topowijo. 2014. "Analisis Kinerja Keuangan Perusa-haan Dengan Menggunakan Metode Du Pont System" Administrasi Bisnis, Vol.16, No.1, November.

Raharjo, Budi. 2001. Dasar-dasar Manajemen Keuangan. Yogyakarta: UPP STIM YKPN
Simora, Henry.2000.Akuntansi : Basis Pengambilan Keputusan Bisnis.Jakarta: Salemba Empat

Soediyono,R.1992.Ekonomi Makro :Pengantar Analisis Pendapatan Nasional.Yogyakarta: Liberty

Warsono, Haryanto. 2003. Pembelajaran Aktif Teori dan Asesmen. Bandung: Rosda

Zakki Falani, Ahmad.2013. Analisis

Laporan Keuangan Perusahaan Sebagai

DasarPengambilan Keputusan Investasi

SahamBerbasis Du Pont System \& Fuzzy

Logic. Universitas Narotama Surabaya.

Surabaya 